УДК 327 (477-574):658.76

DOI:10.24144/2078-1431.2018.1(20).203-216

Petr Tokar,

Candidate of Sciences (Sociology) Foreign professor of the LN.Gumilyov Eurasian

National University (Astana, Kazakhstan)

Sviatoslav Ruban,

PhD student of the LN.Gumilyov Eurasian National University, specialty «Political Science»

\title{
PROBLEMS AND PROSPECTS OF ENERGY COOPERATION BETWEEN UKRAINE AND KAZAKHSTAN
}

This article investigates the history of the formation and prospects of Ukraine- Kazakhstan relations in the energy cooperation as one of the priorities of Ukraine's foreign policy. The analysis of the cooperation of the countries in this area was carried out and the main causes of the crisis in this direction of bilateral relations were determined.

Keywords: Ukrainian-Kazakh relationship, energy cooperation, energy security, diversification of sources.

У статті висвітлено історію становлення та перспективи розвитку украйнсько-казахстанських відносин в енергетичній сфері як один із пріоритетів зовнішньої політики Украйни. Здійснено аналіз співробітництва та визначено основні причини кризи у изій сфері двосторонніх відносин названих крайн.

Ключові слова: українсько-казахстанські відносини, енергетичне співробітництво, енергетична безпека, диверсифікація джерел.

Formulation of the problem. Over the past 25 years, the subject of energy cooperation in the relations between Ukraine and Kazakhstan is a priority. Ukraine is among the energy-deficient 
countries, because using its own fuel-energy resources it meets only $47-49 \%$ of its requirements. Domestic oil production covers $10-12 \%$ of its needs and $20-25 \%$ - of natural gas. As is well known, Kazakhstan possesses proven oil reserves of 4.8 billion tons, which corresponds to $3 \%$ of the total world oil reserves and is among the top ten countries in terms of hydrocarbon reserves. This leads to a logical interest in the supply of hydrocarbon raw materials to Ukraine and through Ukraine to European markets, which will provide indirect access to the Black Sea, strengthen geopolitical significance, and bring political and economic dividends to Kazakhstan. Ukraine, in turn, is constantly trying to strengthen its energy security, and against the backdrop of deterioration in Ukrainian-Russian relations - is looking for alternative sources of required energy. In this area, cooperation with Kazakhstan can become the most priority direction of Ukraine's foreign policy.

Analysis of recent research and publications. The issues of energy cooperation between Ukraine and Kazakhstan remain not sufficiently researched by both Ukrainian and Kazakh scientists. Certain aspects of fuel and energy interaction between countries were considered in the articles of such scholars as R. Opimach [1], N. Kuharskaya [2], V. Saprykin [3], M. Polyakova [4].

The purpose of the study is to conduct a comprehensive analysis of Ukrainian-Kazakh cooperation in the energy sector. The study identified the main directions of cooperation, their current status, the causes of the crisis, as well as the prospects for development.

Statement of the main material. The development of cooperation between Ukraine and Kazakhstan in the energy sector is becoming increasingly important every year and contains the potential for rapprochement and improvement of relations between states. Moreover, in the situation of almost complete dependence on energy supplies from Russia, measures to diversify sources of energy supplies, especially natural gas and oil, should be considered as a key element for ensuring Ukraine's national security and creating conditions for sustainable operation and development of the fuel and energy complex. 
Actually, Kazakhstan's cooperation with Ukraine in the field of fuel and energy can be divided into two spheres: oil-and-gas and nuclear power. The Agreement between the Government of Ukraine and the Government of the Republic of Kazakhstan on the principles of cooperation in the oil and gas sectors was signed back in 1996 [5]. The first agreements on the supply of Kazakh oil and fuel to Ukrainian AES were reached in 1998. The Treaty between Ukraine and the Republic of Kazakhstan on Economic Cooperation for 1999-2009 formed he legal basis for further cooperation in the energy sphere [5].

After the signing of this agreement, a two-day official visit (March 10-11, 2000) of the then Prime Minister V.Yushchenko to Kazakhstan took place, during which the negotiations with Prime Minister K.Tokayev on the development of a common market in the energy sector were held. The leadership of the Ukraine in the early 1990s created the program for diversification of energy sources to Ukraine in the following order: "privatization-modernization-diversification". Working on the practical implementation of the program, a decision that Kazakhstan would take part in the privatization of the Kherson oil refinery was reached. The state shareholding was to be transferred to the management of the company "KazakhOil" and already in 2000 a $60 \%$ of stake in OJSC "Khersonneftepererabotka" belonged to the Kazakh company. Privatization of this refinery could definitely become a profitable investment. Firstly, the opportunity to enter the powerful, energy-dependent market of Ukraine was opened, and secondly, the prospective of moving to the European market took place. The Kazakh side suggested not only to buy out a controlling stake in the refinery, but also to provide funds for the reconstruction and modernization of production. In addition, it was planned to create a network of filling stations in the adjacent areas (with high-quality fuels such as A-95 and A-98). Also, a special interest was chained to investing in the Kherson oil pipeline and the Feodosia oil depot [4].

As is known, it is technologically possible to supply oil from Kazakhstan to Ukraine and, accordingly, to an oil refinery, only 
through Russia via the single Atyrau-Samara pipeline. It was possible to solve this problem by developing alternative ways of hydrocarbon supplies through the territory of Azerbaijan to the Georgian ports, and then to the Kherson oil pipeline (taking into account the proposals to expand the port water area, construction of storage facilities on the Black Sea coast). This project has become another prospective direction for bilateral cooperation in the oil and gas sector.

The Protocol on the deepening of cooperation between the Ministry of Energy of Ukraine and the Ministry of Energy, Industry and Trade of the Republic of Kazakhstan dated 08.09.1999 [5] provided for the establishment of a Ukrainian-Russian-Kazakh consortium on the basis of the Lisichansk refinery and the organization of deliveries of Kazakh oil to this enterprise. However, the Russian company "TNK-BP" privatized the Lisichansk refinery. This circumstance has led the most promising at that time sphere of mutual relations of Ukraine and Kazakhstan to a standstill.

Another priority and new direction of cooperative actions was the "Odessa-Brody" oil pipeline, built in 2001 (length 667 $\mathrm{km}$, capacity - from 9 to 40 million tons). It was assumed that Caspian oil will be supplied from the port of South to the western Ukrainian city of Brody, and then to Eastern and Central Europe via the "Druzhba" oil pipeline. Unfortunately, the Ukrainian side has not previously concluded a series of agreements on the export of oil along this route. Precisely because of the lack of the necessary amounts of raw materials, the route "Odessa-Brody" has not been used for three years. This situation has intensified cooperation between the countries, since the capacities of the Republic of Kazakhstan easily covered the needs of Ukraine. At the end of 2002, according to the results of the agreements between OJSC "Ukrtransnafta" and the oil and gas company "KazMunayGas", a "Transyug" enterprise that was to pump Kazakhstan oil via the Odesa-Brody pipeline was established. Consequently both sides were interested in further development of the project.

By the decree of the Cabinet of Ministers of Ukraine "On signing an agreement between the Cabinet of Ministers of 
Ukraine and the Government of the Republic of Kazakhstan on the terms of delivery of Kazakh oil to Ukraine and its transit through Ukraine" dated August 6, 2003, cooperation was fixed at the legislative level [5]. A little later, on June 1, 2004, Ukraine and Kazakhstan signed an agreement on cooperation in the supply of Kazakh oil to Ukraine and its transit through Ukraine, through which CJSC "KazTransOil" and OJSC "Ukrtransnaft" were to pump Kazakhstan oil through the "Odessa-Brody " to the Europe since 2004. Unfortunately, on the way to the realization of such a profitable project the competitors represented by Russian companies "Lukoil" and "TNK-BP" appeared again.

The Russian company "TNK-BP" actively promoted the idea of the reverse use of the pipeline, that is, to pump annually 9 million tons of Russian oil in the direction from Brody to Odessa, rather than Kazakh oil from Odessa to Brody, as originally planned.

Thus, it was supposed to unload the "Druzhba" pipeline and expand the circle of counterparties by sending Russian oil from Brody to the South terminal and further transporting it to Europe by tankers.

The matter of the reverse use of the pipeline generated heated debate in the Ukrainian leadership, because such an operation mode was not the basis for the development of the Odessa-Brody project. Unfortunately, lobbying the interests of Russian companies in the higher echelons of the Ukrainian government led to the signing of contracts with a group of "TNK-BP" companies to transport Russian oil through the pipeline towards the "Yuzhny" terminal [6]. This caused new problems in ensuring Ukraine's energy security again, strengthening the energy dependence of Ukraine on Russia.

In January 2005, the President of Ukraine Viktor Yushchenko announced his readiness to use the Odessa-Brody oil pipeline in accordance with the project direction, but at the legislative level this initiative was reflected only in 2008-2009. Internal contradictions between the presidential power and the government of Yulia Tymoshenko, and then - V. Yanukovych, were provoked. 
Despite the agreements of the two countries, there are always a number of interested parties in the issues of energy cooperation. In case of resolving the issues of the Ukrainian-Kazakh energy cooperation, such parties were the United States of America, the Russian Federation, the countries of Central and Eastern Europe. US interests were represented by "Chevron Texaco", which offered the Ukrainian campaign of OJSC "Ukrtransnafta" to preserve Kazakh oil in the Odessa-Brody oil pipeline in case of congestion of the Bosporus Strait. Thus, the United States tried to defend its interests in the Central Asian region and block any independent actions of Kazakhstan. However, the Kazakh side repeatedly stressed its intentions to use the Odessa-Brody oil pipeline exclusively for the export of its energy resources to the EU countries, which was more profitable and prospective for the RK and Ukraine.

Another interested party is the Russian Federation. The leadership of the Republic of Kazakhstan has always obligingly taken into account the official position of Moscow, which repeatedly interferes with this or that issue, because of too much interdependence of the two economies. We should not forget that in the energy policy not only public, but also private funds of businesspersons are involved, the purpose of which often does not coincide with the interests of the state and the nation. Therefore, the business plans of oil and gas companies often did not take into account the political situation in the Ukraine-Kazakhstan-Russia triangle, and the reached agreements were not implemented, because Kazakhstan demanded that Ukraine itself should seek solutions to all problematic issues with Russia, primarily related to gas supplies. Such interest of the Russian Federation in the Ukrainian-Kazakh energy cooperation is fixed even at the legislative level and is stipulated in the above-mentioned Agreement between the Cabinet of Ministers of Ukraine and the Government of the Republic of Kazakhstan on cooperation in the supply of Kazakh oil to Ukraine and its transit through Ukraine (Article 6 of the Agreement).

Analyzing the above facts, it is possible to claim with certainty the ambiguous nature of Kazakhstan's relations with Ukraine 
in the energy sphere. On the one hand, official Kazakhstan has never refused to fill its Odessa-Brody pipeline with its raw materials, and then to pump oil to Europe, on the other hand, the case remained at the level of applications and declarations. Obviously, certain external and internal political and economic factors influenced the situation. First, the Odessa-Brody oil pipeline was to be completed before Gdansk. Principal agreements on this project were reached on April 27, 2003 in Brussels, during the conference "Oil transport project "Odessa-Brody": strengthening energy security and integrity of the EU" and were reflected in the signed document "Joint Declaration of the Cabinet of Ministers of Ukraine, Council Ministers of the Republic of Poland and the European Commission in support of the Euro-Asian oil transport corridor." According to this document, Poland was to take a direct participation in the completion of the pipeline to Gdansk, providing funds in the general budget with the European Commission, but as for the current situation, construction has not started. Only on September 15, 2011 the head of the National Security Bureau of Poland Stanislav Kozey voiced the new, actualized position of Poland. He said that Poland is not going to finance the completion of the Polish section of the pipeline to Gdansk. The Polish leadership still does not consider this project to be economically viable and self-supporting, therefore it does not want to assume the whole load of responsibility for its implementation [7]. Secondly, the cooling of relations between Ukraine and the Russian Federation, against the backdrop of the Orange Revolution, led to the blocking and, accordingly, to distancing relations between Ukraine and Kazakhstan. This situation had a negative impact on the economic sphere of relations, since the agreements reached earlier between Kiev and Astana on the supply of oil were not fulfilled by either side in full.

Poland's interest in the development of the Odesa-Brody-Gdansk oil pipeline project resumed in March 2014. Polish Ambassador said to Ukraine Henrik Lytvyn at the briefing that there were legal grounds for such construction from the Polish side, and it would be possible to proceed to investments. "But 
there are no economic reasons for them now: there are no guarantees of supplies of the corresponding amounts of Caspian oil at the relevant price." He noted that in such conditions it was impossible to find investors for the completion of the pipeline. At the same time, G. Lytvyn noted that if proper economic conditions for the project were created, the country would be ready to return to it [8].

As a result of the complex of events, Kazakhstan stopped the transportation of oil through the territory of Ukraine in February 2010. The main reason for this was the formal requirements of the transit operator of "Ukrtransnafta" to "KazTransOil" to consolidate the volumes of supplies and increase the tariff for transit. The true reason was covered by the blocking of the project by the Russian Federation and some internal pro-Russian forces in the RK.

A new impetus in energy cooperation between the countries arose after V. Yanukovich came to power. His personal position on Ukraine's foreign policy has made the development of friendly relations with Russia and Kazakhstan one of his priorities. Against this background, the Ukrainian-Kazakh negotiations in the energy sector have intensified. During an official visit to Kazakhstan on April 7, 2010, agreements on the resumption of oil transit at the level of 6 million tons were reached. On 14 September 2010, Kiev paid an official visit to N. Nazarbayev, during which a number of documents related to the fuel and energy complex were signed. After the meeting of the heads of state, Kazakhstan was to restore and increase up to 8 million tons of oil transportation through the territory of Ukraine, which was stopped in February 2010. In addition, they intended to allow Ukrainian companies to develop oil and gas fields in the territory of Kazakhstan [9]. However, the experts then did not unreasonably doubt the possibility of implementing such agreements without the participation of Russia. Unfortunately, 2011 clearly showed that not all agreements of those negotiations were realized again, because of their blocking of the Russian Federation. Despite active visits (27.04.2010, 23-25.05.2010, 21-22.12.2010) of 
Deputy Minister of Fuel and Energy of Ukraine I.V. Kiryushin in the Republic of Kazakhstan and conclusion of an agreement between JSC "KazTransOil" and OJSC "Ukrtransneft" regarding transit conditions Kazakhstan oil through the territory of Ukraine as of 2012, the transit was never renewed. Against the backdrop of the intensification of Russian-Kazakh cooperation within the Customs Union, the Ukrainian vector in Kazakhstan's foreign policy again disappeared from the agenda. At the same time, transportation to the port of Gdansk (Poland) was still a priority and economically profitable for Kazakhstan. Thus, Ukraine's cooperation with the Republic of Kazakhstan in this sphere was actually limited to oil supplies for the needs of Ukrainian oil refineries. Kazakhstani oil products (fuel oil and diesel fuel) were also supplied, but in order to stabilize the domestic market of petroleum products, the Government of the Republic of Kazakhstan (by its Resolution No. 487 of May 28, 2010) banned the export of gasoline, kerosene and gas oil from the country, which was repeatedly extended.

As for the supply of Kazakh gas to Ukraine, it was provided through the intermediation of "Gazprom", which holds a monopoly position in the market for the transit of Central Asian gas to Europe. In this area energy cooperation of Ukraine with Kazakhstan is blocked by the Russian Federation.

Ukrainian-Kazakh cooperation in the nuclear energy field was carried out in the framework of a joint Ukrainian-Kazakh-Russian enterprise "ucrTVS" to produce nuclear fuel, as the founders of which were made by the NAC "Kazatomprom", the Russian company "TVEL" and the State Property Fund of Ukraine. The authorized capital of the joint venture was formed in the amount of 450 thousand dollars, and the shares of the founders are distributed in equal parts (33.3\% each). The purpose of the enterprise is to create a complete cycle of the technological chain "production of fuel-energy pellets - production of fuel assemblies - energy production." In accordance with the statutory agreement the founders took mutual obligations upon themselves, which make it possible to increase the level of co- 
operation between the industrial complexes of the nuclear power engineering of the three countries in the field of nuclear fuel supply to the Ukrainian NPPs. Unfortunately, this project for the production of nuclear fuel could not be realized either. On August 30, 2017, the State Property Fund of Ukraine sold its stake in the enterprise through an auction, thereby completely withdrawing from the joint project [10].

Aggravation of the political situation in Ukraine (the beginning of the Revolution of Dignity, which was caused by a failure of the political leadership of the country from the legislative consolidation of the course of European integration, the growing corruption and the excessive concentration of power in the hands of Yanukovych), the temporary Russian occupation of Crimea, as well as supporting illegal armed groups in Donetsk and Lugansk oblasts significantly affected the already fragile Ukrainian-Kazakh relations not only in the energy sector but also in general.

By the reason of the suspension of the work of coal mines in the east of Ukraine and in order to avoid the occurrence of a shortage of energy coal reserves for the operation of Ukrainian TPPs, there was a need to find alternative coal supplies to Russia.

On December 22, 2014 N.Nazarbayev paid a visit to Kiev during which the issues of settling the situation in the East of Ukraine, relevant aspects of the international agenda and the main issues of trade and economic cooperation were discussed. The President of Kazakhstan said that coal is planned to be supplied to Ukraine from Ekibastuz. [11].

Unfortunately, despite discussions on the issues of Kazakh coal supplies at the highest level, the transition to practical implementation of them is difficult for several reasons. Firstly, during discussion on use of Kazakh coal for Ukrainian energy enterprises, it was found that its quality characteristics do not correspond to the technical conditions established at Ukrainian TPPs. Secondly, the transit of Kazakh coal passes through the territory of Russia, which, in turn, significantly raises its price. In addition, the Russian Federation completely blocks and does not allow the development of coal supplies to Ukraine. 
Issues of intensifying cooperation in the energy sector were discussed during the two-day official visit of Peter Poroshenko to the Republic of Kazakhstan on October 9, 2015.According to the results of the high-level talks, the Ukraine-Kazakhstan Action Plan for 2015-2017 (Roadmap-5) that outlined the key vectors of bilateral cooperation for the future was signed. Now, the organization of the supply of Kazakh oil to Ukraine and its transit through Ukraine is impossible without Russia's participation. Therefore, it is unlikely to talk about the prospect of increasing supplies of Kazakh oil to Ukraine. President of Kazakhstan Nazarbaev uniquely said: "Deliveries of crude oil to refineries in Ukraine are problematic, because they pass through the territory of Russia" [12].

A similar situation occurs with the supply of Kazakh gas to Ukraine. During the briefing that took place on December 7, 2015, the vice minister of energy of Kazakhstan M. Mirzagaliyev said: "For gas supply to Ukraine, first of all, it is necessary to agree with Russia." He also said that there are no such agreements, and Kazakhstani gas is sold on the border with Russia and this suits the Kazakhstan side [13].

Conclusions and prospects for further research. Summing up, it should be noted that in energy cooperation Ukraine and Kazakhstan have a common goal - to search for the possibility of diversification of import-export flows of energy. For this period, cooperation in this area has developed in the following areas: the transportation of oil and gas through the territory of Ukraine in European countries; construction of oil refineries and oil pumping facilities on the territory of Ukraine; participation of Ukrainian specialists in the repair and construction of oil refining facilities in Kazakhstan. As in other sectors, cooperation in the energy sector has experienced periods of ups and downs that were mainly caused by both internal problems (inconsistency of foreign policy of different presidents of Ukraine, economic crisis, political instability) and external factors (Russian interference in negotiation processes, realization of interests of other leading countries of the world, inconsistent policy of Kazakhstan regarding Ukraine). 
As for the present moment, the prospective directions of bilateral cooperation in the oil and gas industry are:

- Development of the project of the Euro-Asian oil transportation corridor using the Odessa-Brody-Plotsk oil pipeline system;

- The resumption of the transit of Kazakh oil by pipelines of Ukraine towards the EU countries;

- Increase in oil supplies by rail to Ukrainian refineries and seaports;

- Participation of enterprises of Ukraine and Kazakhstan in exploration and development of oil and gas fields, design, construction, reconstruction and repair of objects of main oil and gas pipelines, terminals in Kazakhstan and Ukraine;

- Attraction of Ukrainian scientific centers and structures (NAS of Ukraine, Naukoneftegaz Institute) to design projects in the territory of the Republic of Kazakhstan.

The prospective directions of bilateral cooperation in the nuclear energy field between Ukraine and the Republic of Kazakhstan could become:

- Development of scientific and technical cooperation at a new stage between the institutions of the National Academy of Sciences of Ukraine and the National Nuclear Center of the Republic of Kazakhstan, the Ministry of Education and Science of the Republic of Kazakhstan;

- Training of specialists for the nuclear power industry of the Republic of Kazakhstan and their internship at universities and nuclear power plants of Ukraine;

- Participation of Ukrainian enterprises and specialists in the construction of nuclear power facilities in Kazakhstan.

Also, it is expedient for Ukrainian enterprises and organizations to take an active part in tenders that are held in Kazakhstan for the construction and reconstruction of energy facilities, the modernization of national and regional electric networks. In this respect, an obvious example is the "Zaporizhtransformator" 
factory in the market of the Republic of Kazakhstan, which took an active part in the supply of equipment for the "North-South" transmission lines, and "Turboatom", which took an active part in modernizing the CHPP in the territory of Kazakhstan, as well as modernization Ekibastuz GRES-1 and GRES-2.

\section{REFERENCES}

1. Opimakh R. YE. Nafta Kazakhstanu ta ukrayins'ka perspektyva / R. YE. Opimakh // Stratehichni priorytety. - 2009. - № 2. - S. 23-32.

2. Kukharskaya N. A. K voprosu o dyversyfykatsyy énerhopostavok y rehulyrovanyya razvytyya neftehazovoho kompleksa Ukrayny / N. A. Kukharskaya // Ekonomika promyslovosti. - 2009. - № 2. S.143-149.

3. Saprykin V. Maybutnye hazotransportnoyi systemy Ukrayiny: orenduvaty ne mozhna pryvatyzuvaty! Uroky Kazakhstanu / V. Saprykin // Dzerkalo tyzhnya. - 2000. - № 45. - S. 7.

4. Polyakova M. Spivrobitnytstvo Ukrayiny z Respublikoyu Kazakhstan $\mathrm{v}$ enerhetychniy sferi: problemy ta perspektyvy spivpratsi. Retrieved from: http://history.chdu.edu.ua/article/viewFile/69953/65211

5. Dogovorno-pravovoye sotrudnichestvo // Posol'stvo Ukrainy v Respublike Kazakhstan. Retrieved from: http://kazakhstan.mfa. gov.ua/ru/ukraine-kz/legal-acts

6. Boyko YU. Kompaniya derzhavnoyi vahy // Visnyk Natsional'noyi hazovoyi spilky Ukrayiny, zhovten' 2004. Retrieved from: http:// gasunion.org.ua/visnik-ngsu-32004-perspektivi.html.

7. Pol'shcha ne finansuvatyme dobudovu naftoprovodu Odesa-Brody // UNIAN. - 15.09.2011. Retrieved from: http://www.unian. net/ukr/news/456882-polscha-ne-finansuvatime-dobudovu-naftoprovodu-odesa-brodi.html

8. Pol'sha mozhet dostroyt' nefteprovod "Odessa-Brody" // UNIAN. - 25.03.2014. Retrieved from : https://economics.unian.net/energetics/900386-polsha-mojet-dostroit-nefteprovod-odessa-brodyi.html

9. Glava gosudarstva N. Nazarbayev nakhoditsya s Ofitsial'nym vizitom na Ukraine. Retrieved from: https://www.zakon. kz/184324-glava-gosudarstva-n.-nazarbaev.htm

10. Fond gosimushchestva Ukrainy zakryl sdelku po prodazhe doli 
$\mathrm{v}$ yadernom SP s Rossiyey i Kazakhstanom. Retrieved from: https://abctv.kz/ru/last/fond-gosimushestva-ukrainy-zakryl-sdelku-po-prodazhe-doli-v

11. Vstrecha s Prezidentom Ukrainy Petrom Poroshenko // Ofitsial'nyy sayt Prezidenta Respubliki Kazakhstan. Retrieved from: http:// www.akorda.kz/ru/events/international_community/foreign_visits/page_218767_vstrecha-s-prezidentom-ukrainy-petrom-poroshenko

12. Sovmestnoye zayavleniye Prezidenta Ukrainy Petra Poroshenko i Prezidenta Respubliki Kazakhstan Nursultana Nazarbayeva // Ofitsial'nyy sayt Prezidenta Ukrainy. Retrieved from: http://www. president.gov.ua/ru/news/spilna-zayava-prezidenta-ukrayini-petra-poroshenka-ta-prezid-36109

13. Kazakhstan ne dogovarivalsya s RF o postavkakh gaza na Ukrainu Retrieved from: https://forbes.kz/process/economy/kazahstan_ne_ dogovarivalsya_s_rf_o_postavkah_gaza_na_ukrainu/ 